\title{
Más acá del lenguaje. Melancolía e inmediatez del cuerpo en la obra de Samuel Beckett
}

\author{
Elina Montes (2019). \\ Buenos Aires: Leviatán.
}

0

Noelia Billi

Universidad de Buenos Aires, Argentina

Como indica en las "Palabras liminares" Lucas Margarit, la fascinación de Beckett por las figuras de lo melancólico es un punto de observación de alto rendimiento de la obra del escritor irlandés. Elina Montes invita a recorrer ese viaje un poco alucinatorio con un nivel de detalle que honra su extenso conocimiento del corpus beckettiano. A la erudita reconstrucción de las formas en que la tradición occidental ha postulado al melancólico (a la que volveré en un momento), Elina ha adosado una original propuesta: construir unos lentes 3D (sí, como los de los cines) para que les lectores podamos apreciar el volumen material de esos dispositivos que, escritos con precisión milimétrica, hacen de las palabras el modo de imaginación sensible de una cosmopoética que solo por descuido podría entenderse como meramente lingüística. "Los textos nos fuerzan a reponer las condiciones negadas de visibilidad, a preguntarnos por el origen de las voces, por el destino de los cuerpos que las encarnan y sostienen en su progresiva y mutua disolución" (31) escribe la autora, recuperando subrepticiamente aquella idea de fascinación que alguien alguna vez definió como el efecto de la inversión de la mirada calculadora del sujeto, por la cual son las imágenes las que nos atrapan y nos obligan a ese juego imposible que es el de ser tocados a distancia y en el cual es imposible no ver.

La autora le dará la merecida jerarquía al anti-idealismo que domina la obra del irlandés en el último capítulo del libro, donde destacará la significatividad material de los cuerpos (ese sensorium asubjetivo construido por máquinas digestivas, motoras, inmundas) como tergiversación del dualismo cartesiano. Aquí se advierte la agudeza de plantear la melancolía como el punto de referencia para eludir los lugares comunes que reducirían a Beckett a una economía del discurso intracraneal, como el interlocutor privilegiado del ya gastado giro lingüístico que lo mantuvo cautivo durante un largo tiempo. Tal como es desarrollado minuciosamente en el capítulo primero, la innovación introducida en el texto atribuido a Aristóteles -Problema XXX,
1- que señalara Julia Kristeva, ubica a la melancolía en el ethos, es decir, en el área formada por el triángulo entre el individuo, lo sagrado y lo social. El melancólico como figura residirá, pues, en un espacio que trasciende lo meramente patológico para convertirse en el lugar en que el cuerpo aparece como una construcción conjunta de fuerzas espirituales y sociales; o dicho de otro modo: como la materialización de una política y una imaginación. Que estas fuerzas sean vehiculizadas por unos humores somáticos de equilibrio inestable constituye el modo en que la antigüedad resolvió la relación entre un exterior y un interior (del individuo) que será el legado maldito de toda la tradición occidental. Como es sabido, de acuerdo con la teoría humoralista, es la predominancia de la bilis negra a la que se le atribuirá el surgimiento del carácter melancólico, y ya en el Renacimiento queda establecido que ese modo inestable de ser -en el cual se pasa en un instante ingobernable de lo frío a lo caliente, de la apatía a la euforia, de la indiferencia a la creatividad genial-guarda particular afinidad con el temple artístico y la reflexión filosófica. En todo caso, el sujeto melancólico, explica la autora, ha sido el objeto de obsesivos análisis por su carácter excepcional. Elusivo a la tipificación, porque su rasgo más destacado es el de la exterioridad, ha desencadenado toda suerte de clasificaciones de las que irremediablemente se halla exiliado (6o). Y es, quizá, en la lírica amatoria recuperada en el stilnovismo renacentista donde se condensa la desdicha del deseo melancólico, allí donde el otro se constituye como extraño radical no solo por inalcanzable sino por indecible e infigurable (62). Una afección tal, de carácter indiscerniblemente somático-espiritual, en parte explica la utilidad de la figura del melancólico para desgranar las relaciones variables entre las distintas áreas del saber (teología, medicina) que harán eclosión sobre todo durante la modernidad, cuando la emergencia de las ciencias positivas empujen los análisis de la corporalidad hacia el terreno de la mecánica. Desde este punto de vista, la autora reconstruye las teorías mecanicistas del 
cuerpo humano que describirán al melancólico como el resultado de un conflicto social (antes que religioso) que impacta en el delicado sistema hidráulico que es el cuerpo. En este locus político, en que salud moral y salud física deben confluir armónicamente, la melancolía se prefigura como un mal epocal, "vinculado a las ansiedades provocadas por los ritmos urbanos $y$ al rechazo de una dinámica marcada por las prerrogativas del mercado" (74). No obstante, aquel aire triste y ceniciento que caracterizaría al sujeto melancólico será, posteriormente, encorsetado por la nosología de la naciente psiquiatría bajo una forma que perdura hasta el presente: la depresión. Así, el rastreo de la melancolía como subjetividad emergente de condiciones sociohistóricas de existencia comunes que realiza Elina en un recorrido exquisito que amalgama ficción y teoría, ilumina la exclusión social cuya violencia fría contrasta con el refugio frágil que la subjetividad melancólica encarna, y cuyas formas más comunes en el siglo XX serán el intelectual (en la línea benjaminiana) y el marginado social: dos formas de retracción social que oscilan entre la inoperancia resistente y la lucha activa contra la agresión (96-97).

Si antes me refería a los lentes 3D que Elina construye amorosamente en esta obra es porque los interrogantes que diseñan su lectura buscan mostrar la forma particular en que la dinámica entre el adentro y el afuera se materializan en el cuerpo beckettiano, y esto entendido tanto en sus prácticas de lector-escritor como en los efectos sobre una escritura que busca anclar la discursividad enloquecida en objetos concretos; es decir, allí en ese resquicio donde la palabra es una cosa del mundo y el mundo algo hecho también de palabras. En cuanto a las prácticas de lectura de Beckett que lo muestran como un lector sutil y riguroso, en el capítulo 2 la autora se detiene en las imágenes que el irlandés elabora de la poesía medieval (algunos subgéneros plañideros de la poesía trovadoresca y de minnesinger, como el alba, el planh y el enueg) tanto en el poemario temprano Echo's bones (de 1935) como en la tardía Stirring Still (de 1988). A partir de esta referencia, las imágenes de inmovilidad profunda que inundan la obra beckettiana se conectan con el desacople entre una naturaleza plétora y una subjetividad incapaz de alcanzarla que las poéticas medievales manifestaban con gestos típicamente melancólicos: el desconcierto ante el tiempo que ha pasado sin poder ser experimentado y que acecha como el fantasma de un ayer perdido para siempre y, por eso, causa de un duelo imposible de superar. Tal como explica Elina, la ausencia de intercambios vitales con el entorno, característica de la subjetividad saturniana, en Beckett produce escenarios inhóspitos y malsanos donde la descomposición afecta por igual a objetos y sujetos, cuya consecuencia es la disolución de ambos polos de la ecuación epistemológica (125). En Watt, en Mercier et Camier, en Molloy, en Breath (los casos que analiza la autora) la desintegración de las materialidades no genera en los sujetos un ánimo de superación que los ubicaría en el sano lugar de la redención por la vía del espíritu de la inmundicia terrestre, sino indiferencia, tedio, una estasis desesperanzada. $Y$ esto permite comprender en toda su extensión el lugar atípico en que el vínculo lingüístico opera en la obra del escritor irlandés: descartadas la comunicación o la expresión (funciones siempre de una interioridad que solicita una salida al exterior), las voces sin destino y muchas veces sin emisor remiten a la indeterminación del origen, al instante preteológico en que la materialidad inaprehensible prescinde del individuo (134). Es evidente, entonces, por qué aquí el motivo que debe ser trabajado es el del fango: porque a contramano de la tradición que lo enaltece como mera materia disponible para la manipulación del verbo divino, Beckett lo sitúa literalmente en la boca. "La langue se charge de boue" escribe el autor irlandés en Comment c'est, y Elina señala acertadamente que es allí donde se accede al significado primordial que Beckett atribuye al lenguaje: un castigo, la insoportable humanidad. Así figurada, la lengua enlodada es la imagen que da cuerpo a la maldición que Beckett transforma en proyecto: la escenificación de una "static lifelessness" anti-teológica y anti-teleológica abocada a destruir la "terrible materialidad de la superficie de las palabras" y bucear en los "insondables abismos de silencio" (como escribe el autor en la "German Letter" de 1937, 150-151).

Llegado este punto del recorrido, nuestros lentes 3D permiten admirar aún más (si esto fuera posible) las herramientas mínimas con las que Beckett logró figurar la oscilación entre un adentro vacío pero colérico y un afuera cíclico y tantálico (168). Vemos al propio texto del irlandés funcionar así como un péndulo un poco hipnótico que insiste en marcar las repeticiones que erosionan todo rasgo de individualidad, y hacen de cada acción y de cada cosa el eco de alguna otra. Así, como analiza minuciosamente la autora, es el cilindro fatídico de Le Dépeupleur el elemento que permite a Beckett desplegar desapasionadamente las formas en que la des-subjetivación radical tiene lugar paradójicamente en un dispositivo perfecto de captura y subjetivación. “¿Qué significaría 'despoblar' en este contexto o, siguiendo el título en inglés del relato [The lost ones], hallar lo que se ha perdido?" (18o181) se pregunta Elina Montes dando lugar al juego intertextual con Dante que resalta el contraste entre la peregrinación ascensional y purificación espiritual que impera en la estructura de la Commedia, y la fallida 
utopía laica beckettiana donde lo único cierto es que por más frenesí que se aplique a la búsqueda, no hay salida. Constituye un hallazgo el rastreo de toda esta cinemática pendular en Krapp's Last Tape (de 1958), Footfalls (de 1976) y Rockaby (de 1981), donde es llevada a su mínima expresión a través de la circulación de los personajes por zonas de luz y de sombra (192-200). A la intermitencia perceptiva que doblega cualquier idea de continuidad corporal se le adosan distorsiones sonoras que desacoplan las voces de cualquier emisor figurable, todo lo cual confluye en la emergencia de una dimensión temporal suplementaria (un pasado remoto, nunca acontecido) que envuelve el presente en una bruma fantasmal y materializa el estado del melancólico, el habitante único de un mundo espeso en el que no pasa nada pasible de ser experimentado en primera persona.

Le pesa el cuerpo al melancólico. Al menos eso parece si se observan sus morosos movimientos, más afines a la temporalidad expandida de las plantas (casi imperceptible para el ojo humano) que a la rapaz traslación del animal humano. Pesadez que proviene de un repliegue en la interioridad, cual si fuera el resultado de una oposición entre un cuerpo ajeno y una voz frágil pero propia (como ha sido recurrentemente interpretado por la crítica) y que, como acertadamente señala la autora, representa un abordaje solidario de la antropología dualista cartesiana que fuerza a oponer materia y mente. La corporalidad extrañada del melancólico recorre estas vías pero exponiéndolas al desafío de llevarlas al límite y es en esta última parte del ensayo de Elina Montes que puede advertirse cuán oportuno ha sido el andamio que ella ha construido para estar a la altura del agudo tratamiento beckettiano del tema. Ese límite tiene una localización muy precisa, una zona donde se despliega la batalla final por las fronteras entre el adentro y el afuera, lo viviente y lo inerte: la caja craneana. Retomando la delicada lectura que Didi-Huberman hiciera de este locus clásico de las artes en Ser cráneo, Elina muestra cómo la obra de Beckett describe el movimiento pendular que va del cráneo pensante (sujeto que vive en y de sus ideas) a la calavera, símbolo transhistórico de la descomposición final de la forma humana en su retorno a la naturaleza fósil de la piedra ajena a toda vida y experiencia. Ofreciendo un testimonio sobrio pero desgarrador de la imposibilidad de dar cuenta de la experiencia de un mundo atroz, "el lenguaje arrastra a los personajes hacia adentro y aspira vanamente a convertirse en silencio, mientras que un magma orgánico en el que concurren el dolor, el asco y el hastío desvía de la palabra rumiada y proyecta hacia un afuera en el que se juegan las vicisitudes del cuerpo" (235). Y allí, precisamente afuera, es el único lugar donde el lenguaje se hace una cosa más, vida fosilizada o imagen móvil inhumana, un afuera que extiende sus tentáculos hasta el interior solo para mostrar la inútil pasión que es, para el individuo melancólico, vivir.

Elina Montes nos ofrece un libro que es desafiante en su multiplicidad de fuentes y de lenguas, tan exhaustivo con la obra beckettiana como amable con sus comentaristas, con quienes conversa profusamente. La documentación de los intertextos, junto con un sólido marco teórico nutrido por nociones provenientes tanto de la teoría literaria como de la filosofía y el psicoanálisis, iluminan el estado actual de los estudios sobre Beckett, a los que aporta sus bellos lentes. 